2016, volume 5, issue 2

Piotrowska, A. (2016). Fields of potential use of cryptocurrencies in the payment services market in Poland - results of an empirical study, 5(2), 201-217. http://dx.doi.org/10.12775/ CJFA.2016.023

\author{
Anna Imona Piotrowska*
}

WSB University in Toruń

\title{
FIELDS OF POTENTIAL USE OF CRYPTOCURRENCIES \\ IN THE PAYMENT SERVICES MARKET IN POLAND - RESULTS OF AN EMPIRICAL STUDY
}

Keywords: Smart cryptocurrency, bitcoin, digital payments, financial innovation.

J E L Classification: G20, E42, 031.

\begin{abstract}
The payment services market in Poland is particularly open to new payment solutions. The most important financial innovations of the recent years include cryptocurrencies. Bitcoin is the most well-known of them and its applications cover payments and investments. The article aims to determine the potential for using cryptocurrencies in individual segments of the payment services market in Poland. The paper considers the following research hypothesis: Representatives of the financial sector see a potential for a widespread use of cryptocurrencies in the payment services sector in Poland. The aim of the paper was achieved and the hypothesis verified on the basis of selected results of a survey among representatives of institutions operating in the financial market in Poland. The study, primarily carried out by the author, presents the opinions of experts representing the broadly understood community of professionals from the payment services market in Poland. Their views concern the directions in which innovations in the payment services sector may develop and the prospects for the use of cryptocurrencies in that area.
\end{abstract}

Date of submission: December 14, 2016; date of acceptance: January 23, 2017.

* Contact information: anna.piotrowska@wsb.torun.pl, WSB University in Toruń, Młodzieżowa 31a, 87-100 Toruń, Poland, phone: +48 566609217. 


\section{INTRODUCTION}

For over 10 years, the financial sector in Poland has been witnessing the introduction and testing of many innovative payment solutions (Polasik \& Piotrowski, 2016; Świecka, 2015; Harasim \& Klimontowicz, 2013). Poland was the pioneer with regards to the widespread use of contactless card payments. It was also the Polish market where the first $\mathrm{NFC}^{1}$ mobile payments in Europe were implemented (Polasik, 2014). The dynamic increase in the turnover of electronic commerce, coupled with a growing number of users of modern telecommunication devices, such as smartphones and tablets, results in a substantial potential for development of the mobile payments market in Poland. It also gives an opportunity to increase the share of mobile payments in the retail payments sector. This gives rise to strong competition between the participants of that market. Banks are no longer the only institutions active in the payments market: new market players emerge, such as mobile operators and virtual payment services. Although currently the share of non-banks in the payments market in Poland and globally is minute, it is poised for rapid growth (World Payments Report, 2013, p. 15).

Only in the recent years have the statistical data of international financial institutions started including cryptocurrency transactions among payments carried out outside the banking system (World Payments Report, 2015). According to the international research agency Capgemini and The Royal Bank of Scotland, they are one of the four main categories of hidden payments ${ }^{2}$. The share of unreported transactions in the total number of cashless transactions may reach around $10 \%$, and the share of cryptocurrency transactions was estimated at $0.01 \%$. Therefore, payments with cryptocurrencies are currently only a small portion of cashless transactions. However, their existence should not be ignored or disregarded because their share is expected to rise, primarily due to the growing number of merchants accepting retail payments made using cryptocurrencies (mainly bitcoin) and a strong interest of the media (World Payments Report, 2015, p. 16-17).

While the emergence of a completely new technological solution in the form of cryptocurrencies in the payment services market characterised by fervent

${ }^{1}$ NFC - Near Field Communication.

2 The authors of the report understand hidden cashless transactions as transactions carried out by non-banking institutions which are not required to report payment transactions. 
competition may be considered a huge challenge faced by the whole sector, it may also be perceived as an element of competitive advantage. The several years in which bitcoin and other cryptocurrencies have been used have proven that this kind of payment system and tender operate smoothly. Therefore, individual participants of the financial market, and banks in particular, may be interested in using cryptocurrencies in the business they conduct. In light of the above, it seemed very interesting to learn the opinion of experts from the Polish payments market regarding the prospects for the use of cryptocurrencies in individual segments of the payment services market in Poland. The paper considers the following research hypothesis: Representatives of the financial sector see a potential for a widespread use of cryptocurrencies in the payment services sector in Poland.

\section{THEORETICAL FRAMEWORK AND LITERATURE REVIEW}

Bitcoin is the leading and the longest-functioning cryptocurrency. The idea behind it was presented in 2008 in the paper Bitcoin: a peer-to-peer electronic cash system written by an anonymous author (or group of authors) under the pseudonym Satoshi Nakamoto (Nakamoto, 2008) ${ }^{3}$. The notion of bitcoin may refer to the unit of value, but also to the IT system which is the framework for effecting payments using the bitcoin cryptocurrency (Badev \& Chen, 2014, p. 2). A. Sieron defines bitcoin as a means of exchange, and at the same time: "the open-source software and the peer-to-peer (P2P) network which it forms" (Sieroń, 2013, p. 32). In turn, L.P. Nian and D.L.K. Chuen describe bitcoin as: „a decentralized network and a digital currency that uses a peer-to-peer system to verify and process transactions" (Nian \& Chuen, 2015, p. 14). E. Grover deems bitcoin to be: "a decentralized digital currency and payment system" (Grover, 2014, p. 39). J. Brito and A. Castillo expand this approach by defining bitcoin as: "the world's first completely decentralized digital currency (...) and

${ }^{3}$ It should be noted that despite many attempts, the identity of the bitocin's creator was not established. The following cryptologists are named among the potential authors of the concept of bitcoin: W. Dai, N. Szabo, H. Finney. It is also sometimes claimed that persons behind the creator of the said cryptocurrency may be related to the four technological companies: SAmsung, TOSHIba, NAKAmichi, MOTOrola. See more: Coindesk, Who is Satoshi Nakamoto, http://www.coindesk.com/information/who-is-satoshi-nakamoto/ (accessed: 26.08.2016); Nian, L.P., Chuen, D.L.K. (2015). Introduction to Bitcoin. In L.K. Chuen (Ed.), Handbook of Digital Currency. Bitcoin, Innovation, Financial Instruments, and Big Data, p. 11, DElsevier. 
world's first completely decentralized digital-payments system" (Brito \& Castillo, 2016, pp. 1, 5).

Although works on the creation of digital, and more precisely - "cryptologic" money characterised by anonymity and decentralisation had been performed among different groups of researchers, and cryptologists in particular, for over thirty years (Franco, 2015, p. 161; Barber, Boyen, Shi, Uzun, 2012, p. 39; Moore, 2013, p. 147), the announcement of the Nakamoto manifesto initiated a period of wider interest in the issue of cryptocurrencies.

The study of available literature indicates that authors of different publications focused primarily on the idea behind the inception of bitcoin and matters of definition (Selgin, 2015; Yermack, 2013; European Central Bank, 2012; International Monetary Fund, 2016), the technical aspects of the bitcoin system (Courtois, Grajek, Naik, 2014; Vasek, Thornton, Moore, 2014; Ober, Katzenbeisser, Hamacher, 2013), the analysis of the investment behaviour of cryptocurrency users (Baek \& Elbeck, 2015) and the identification of factors determining the bitcoin exchange rate (Kristoufek, 2015; Li \& Wang, 2016; Polasik, Piotrowska, Wiśniewski, Kotkowski, Lightfoot, 2015). The author observed that the potential use of bitcoin in payments, which was at the foundation of the bitcoin idea, has not been sufficiently examined in research and literature on the subject. Having that in mind, she decided that the paper would specify the potential use of cryptocurrencies in the Polish payment services sector.

\section{RESEARCH METHODOLOGY AND COURSE OF THE RESEARCH PROCESS}

The research hypothesis was verified on the basis of selected results of the survey among representatives of financial institutions operating in Poland. It was carried out in cooperation with the Polish Bank Association between June and December 2014 as part of a research project of the Warsaw Institute of Banking and ALTERUM Grant No. WIB/2014/01, „Rozwój przez innowacje czy efekt skali? Badanie uczestników polskiego systemu płatniczego" ${ }^{4}$. It covered a number of cognitive goals concerning the broadly understood issue of develop-

4 The author would like to thank Michał Polasik Ph.D. and Natalia Kumkowska who also served as investigators. Moreover, special thanks are addressed to Lech Kurkliński, Ph.D., the director of ALTERUM, director Paweł Widawski, Ph.D. and Radosław Kotkowski from the Polish Bank Association for their support in carrying out this research project. 
ment and innovation in the payment services market. One of the aims was to determine how the bitcoin cryptocurrency could function in the financial system. The study intended to discover the scale of interest in the potential use of cryptocurrencies, including bitcoin, in the financial sector and to specify the prospects for the development of the cryptocurrencies market. The author was among the investigators of the project, and her duties included developing the questionnaire and analysing the obtained results. She was also responsible for analysing the results of the study related to cryptocurrencies and the biometric technology (selected questions in individual parts of the survey) ${ }^{5}$.

The study, which generated the original source material, was addressed to high-level managers employed in commercial banks, cooperative banks operating in Poland and their associations, banking sector institutions (the National Bank of Poland, the Polish Bank Association), the national clearing house (KIR), card associations, domestic payment institutions and IT companies functioning in the area of payment services, as well as acquirers. The Polish Bank Association had a key role in the implementation of the study. It selected 470 experts dealing with innovation in the financial market within the surveyed institutions, and distributed the questionnaire through its associated entities, i.e.: the Council of Bank Cards Issuers, the Electronic Banking Council, the Clearing Agents Committee and SEPA Poland. The questions regarded opinions and forecasts of experts participating in the survey, and not the position of the parent institution.

The study generated responses from 70 experts, who presented the opinions of the broadly understood community of professionals from the payment services market in Poland. Information regarding the respondents is presented below.

${ }^{5}$ Results of the study were published in the form of a report: Polasik, M., Piotrowska, A.I., Kumkowska, N. (2015). Rozwój przez innowacje czy efekt skali? Badanie uczestników polskiego system płatniczego, Research report, ALTERUM Centre for Research and Analysis of Financial System, Warsaw Institute of Banking, Warsaw. 
Figure 1. Positions held by the respondents

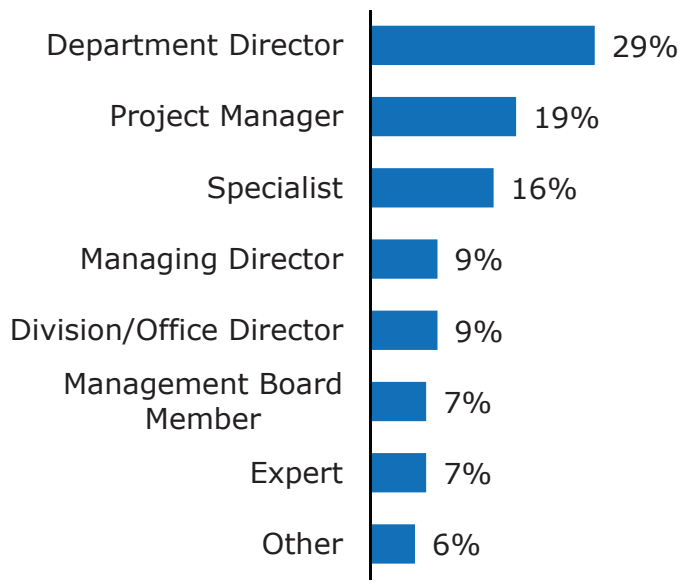

S o u r c e : survey of representatives of institutions operating in the payment services market in Poland, $\mathrm{N}=70$.

The research sample in terms of the positions held by the respondents is presented in Figure 1, which shows that most of them boast high competence with respect to the subject matter and decision-making. According to the author, it may be treated as one of the factors supporting the high cognitive value of the survey.

Figure 2. Type of institution employing the experts

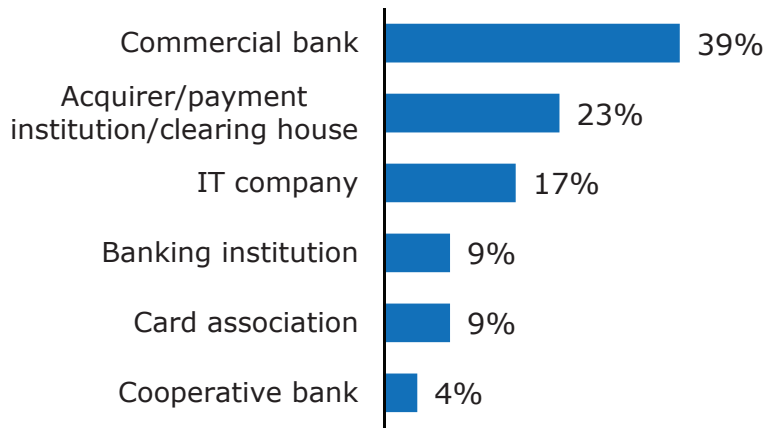

S o u r c e : survey of representatives of institutions operating in the payment services market in Poland, $\mathrm{N}=70$. 
Figure 2 presents the type of institutions which employ experts participating in the survey. The respondents worked in most types of financial institutions functioning in Poland, which make up the infrastructure of the payment services market. The most numerous group included the employees of commercial banks (almost 40\%). It should be noted that responses were given by employees of the five largest banks in Poland in 2014 in terms of assets managed (50 największych banków w Polsce, 2015). Other groups with a high share included experts from institutions processing and settling payment transactions (23\%), as well as IT companies providing solutions for the payments sector $(17 \%)$. Additionally, the questionnaire also involved the representatives of leading banking institutions and card associations, as well as the employees of cooperative banks. Such high range of the questionnaire survey allowed its authors to obtain expert opinions regarding diverse aspects of the functioning and development of the cryptocurrencies market. This fact should undoubtedly be treated as an advantage of the survey. Moreover, the study of literature regarding cryptocurrencies has shown that research in that field has not yet been carried out in Poland.

\section{OUTCOME OF THE RESEARCH PROCESS}

The experts participating in the survey were asked to indicate the most important challenges facing the Polish payments sector by the years 2015 and 2020 . Cryptocurrencies, including bitcoin, were presented as one of the many potential issues to be addressed by market participants. The broad range of possible answers allowed the researchers to determine the materiality of cryptocurrencies vis-à-vis other market changes, whether occurring or anticipated. Figure 3 presents all answers given to that question for the two analysed time frames. Only selected responses are subject to a more in-depth analysis further in the paper. 
Figure 3. The biggest challenges in the Polish payments market by the years 2015 and 2020

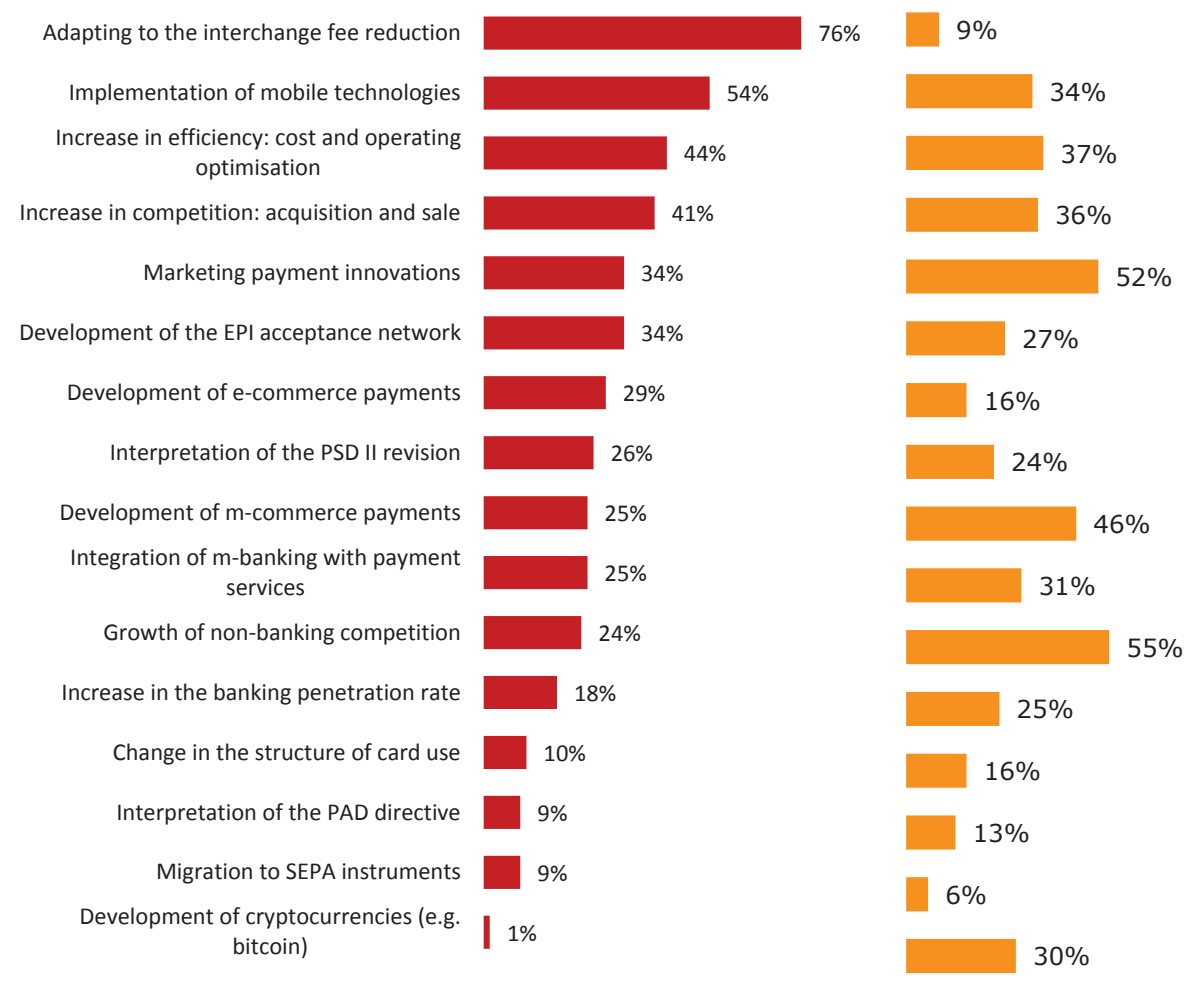

S o u r c e : survey of representatives of institutions operating in the payment services market in Poland, a maximum of 5 answers, $\mathrm{N}=67-68$.

In the opinion of the respondents, in the 2015 time frame cryptocurrencies did not form a significant challenge for the payments market in Poland (Figure 3). They claimed that regulatory issues were the most important shortterm challenge in Poland. As many as $76 \%$ of the respondents pointed to the need to adjust to the interchange fee reduction. This indicates that the role of the regulatory factor in the payment services market is pivotal. Statutory changes may either stimulate or hamper the development of the given payment instrument or service, which has already been signalled by certain researchers (Harasim, 2013). Therefore, it may be assumed that a broader use of cryptocurrencies in the payments market will be largely dependent on the legislation.

The second most important challenge (more than $50 \%$ of indications) was the implementation of mobile technologies (Figure 3). It is worth noting that 
this factor should be considered as beneficial for the potential for using cryptocurrencies in the payments area. This is due to the fact that mobile technology is the natural environment for bitcoin and other cryptocurrencies. The experts also pointed to the detailed issues related to the development of mobile technologies, such as the introduction of m-commerce payments ${ }^{6}(25 \%)$ and the integration of mobile banking with payment services (25\%). It should be mentioned that the increase in the number of banking mobile applications currently observed in the Polish market (the Public Relations Office of the Ministry of Treasury, 2014), as well as in the number of people making payments from a mobile application (Mikowska, 2015), together with a change in habits regarding the payment methods used, may also indirectly impact the development of payment applications of bitcoin.

In the case of the long-term perspective, the significance of individual challenges facing the participants of the Polish payments market changed substantially (Figure 3). It should be emphasised that as many as $30 \%$ of the experts indicated cryptocurrencies is one of the biggest challenges in the Polish payments market in the 2020 time horizon. Likewise, the development of cryptocurrencies was the factor which gained most prominence in the 2020 perspective from among the challenges indicated in the question. This means that despite the currently niche nature of that solution, the payments community anticipates that it may grow dynamically by the year 2020 and create significant challenges for current market participants. Moreover, while in the short-term few experts saw the risk that non-banking competition would gain a share in the market, in the 2020 time horizon this process became the most prominent for the current participants of the payments market. One of the answers of the financial sector to that challenge would be a more intensified introduction of payment innovations (over $50 \%$ of indications). It may turn out that cryptocurrencies or the underlying technologies will become one of such innovations used by banks.

The survey also provided an overview of the respondents' forecasts regarding the development of four market segments with the potential for payment applications of bitcoin and other cryptocurrencies, i.e. transactions in points of sale (POS), e-commerce, m-commerce and person-to-person (P2P) settlements. The respondents rated the popularity of different types of innovative payment methods on a scale from 1 to 5 ( 1 was marginal use and 5 widespread use) for two time horizons, the years 2015 and 2020.

6 Transactions in mobile commerce are defined as transactions starting and ending on a mobile device. 
Figures 4 and 5 present indications of the respondents referring to cryptocurrencies as compared to the most probable payment solutions in the analysed market segments. Such juxtaposition is aimed to learn which solutions the market will turn to and which technologies will be the potential competitors of cryptocurrencies.

Figure 4. Forecast popularity of selected payment methods in individual market segments by $2015^{*}$

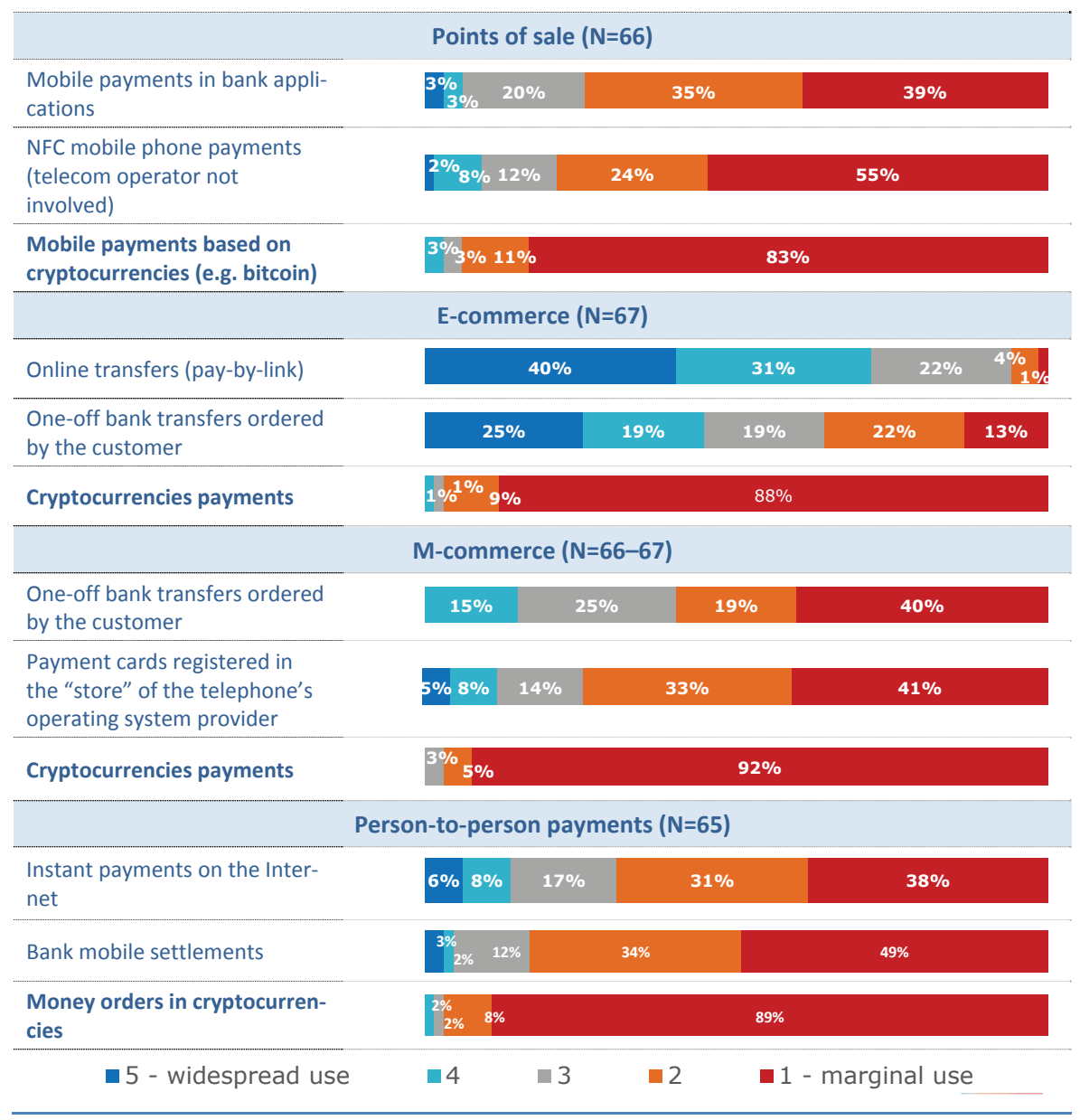

* Due to rounding, the aggregate result of the answers does not always add up to $100 \%$.

S o u r c e : survey of representatives of institutions operating in the payment services market in Poland. 
In the opinion of the responding experts, by the year 2015 cryptocurrencies, including bitcoin, would not be used in any of the analysed market segments (Figure 4). What is more, the experts believed that none of the inoperative payment methods indicated in the questions would gain popularity within the abovementioned time frame. This may have resulted from the fact that gaining widespread popularity by a given payment service, instrument or method is a time-consuming process which calls for the involvement of many market participants, whereas the cryptocurrencies market, although experiencing dynamic growth, is still in the early stages of development.

In the case of transactions in points of sale, the vast majority of experts believed that none of the proposed innovations would be used on a broader scale (Figure 4). It is worth indicating that transactions in this field, due to strong domination of cash and traditional payment cards, are undoubtedly a difficult area for implementing innovation, especially such as cryptocurrencies. The belief of $6 \%$ of experts regarding the moderate scope of bitcoin may result from the fact that bitcoin has been known to be accepted in individual points of sale in Poland. However, despite the fact that such POS truly exist, only several of them carry out cryptocurrency transactions on a fairly regular basis ${ }^{7}$.

E-commerce cryptocurrency use obtained a slightly lower number of indications as compared to transactions carried out in points of sale, which may be somewhat surprising. The field of m-commerce, where a broader range of bitcoin use could be expected, would also have no use for this cryptocurrency in the 2015 perspective. The mobile commerce segment in Poland is currently at an initial stage of development, and this was probably reflected in the very negative outlook on the use of all of the payment methods by 2015 (Figure 4).

Person-to-person payments were the last of the analysed fields where cryptocurrencies could be used. In Poland, they are dominated by cash and traditional wire transfers. Therefore, in the 2015 time horizon the experts rated the chances that any of the innovative methods would gain popularity as marginal or slim (Figure 4).

The experts forecast that by the year 2020 (Figure 5) certain types of innovative payment methods would be very popular; however, they were very conservative when it came to cryptocurrencies.

7 Information obtained from a leading intermediary to cryptocurrency transactions in Poland (11.07.2016). 
Although in their opinion cryptocurrencies would not play a significant role in the area of POS payments, their projections were more optimistic than those regarding the year 2015: there could be an increase in the use of cryptocurrencies. This may be related to the forecast development of app-based mobile payments or a possible development of a network of merchants accepting cryptocurrencies.

Figure 5. Forecast popularity of selected payment methods in individual market segments by $2020^{*}$

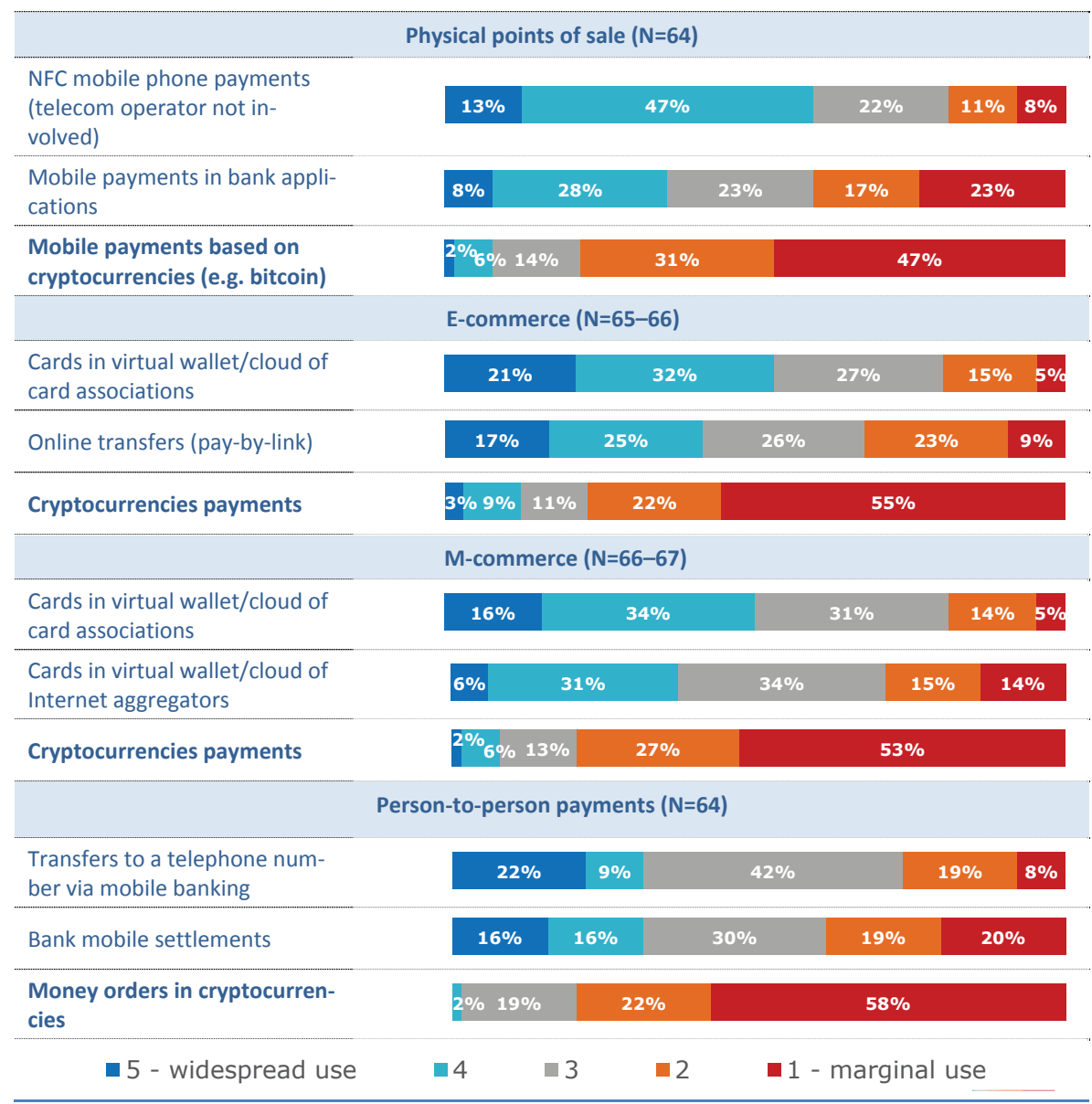

* Due to rounding, the aggregate result of the answers does not always add up to $100 \%$.

S o u r c e : survey of representatives of institutions operating in the payment services market in Poland. 
In the 2020 time horizon, the experts anticipated a substantial change in the popularity of payment methods in electronic commerce as compared to the expectations voiced for the year 2015 (Figure 5). The respondents expected that the leading role would be played by the following technologies: solutions based on cloud computing and payment cards placed in virtual wallets of card associations ${ }^{8}(53 \%$ rated 5 or 4$)$ or Internet aggregators ${ }^{9}(42 \%)$. This process would give rise to a very significant increase in the role of payment cards in ecommerce payments at the expense of bank transfers. Interestingly, payments using bitcoin and other cryptocurrencies would not go into widespread use despite the fact that online transactions are the most suitable field in which they may be used. However, it should be noted that the field of e-commerce obtained the highest percentage of positive ratings in terms of the use of cryptocurrencies $(12 \%$ rated 5 or 4$)$ from among all of the analysed market segments.

The study also covered the potential use of cryptocurrencies in mobile commerce transactions. According to the experts, m-commerce payments using cryptocurrencies would not have developed also by the year 2020 (Figure 5). However, it should be noted that $8 \%$ of ratings ( 5 or 4 ) suggested their widespread use in this payments area in the longer term (there were no such ratings in the 2015 perspective). On the other hand, solutions based on payment cards would be fairly popular.

The respondents claimed that in the 2020 time horizon, the segment of person-to-person payments (Figure 5) would be led by transfers to a telephone number via mobile banking, while cryptocurrencies would be used only marginally (only $2 \%$ with a 4 rating).

The last field where cryptocurrencies may be used that was analysed in the paper involves prepaid instruments. Currently, virtually all available bitcoin uses are associated with the need to credit a prepaid instrument with the cryptocurrency. The instruments most often take the form of an electronic purse based on a mobile application. It was thus interesting to learn how the respondents would answer the question regarding the types of prepaid instruments which would be prevailing in 2020. They could also indicate whether the technology used to construct cryptocurrencies would be used to develop a given type of instruments (Figure 6). The answers of the experts suggest that none of the anticipated directions of development in the area of prepaid instruments

8 E.g. within MasterPass and V.me by Visa.

9 Aggregators best-known in Poland: PayPal, PayU. 
will be based on the principles underlying the bitcoin system and systems created for other cryptocurrencies. Only $26 \%$ of the respondents indicated that the currently-popular prepaid cards in the traditional, plastic form would retain their position. In light of the above, the attempts to introduce prepaid cards credited with bitcoins should be seen as bearing little sense ${ }^{10}$. The respondents were of the opinion that the dominant role in the field of prepaid instruments will be played by electronic purses associated with a mobile application. This response was indicated by almost half of the surveyed experts. An additional $18 \%$ pointed to virtual purses, such as PayPal, which sums up to $64 \%$ of the experts who found that the most prospective solution would be based on a mobile or virtual purse. In the context of the answers given by the respondents, the prevalent method of storing files with bitcoin value, namely an electronic purse associated with a mobile application, seems to be the right solution. The plans of PayPal, a global leader in the payments industry, should also be mentioned. They concern extending the functionalities of the services provided by adding an option of charging the virtual wallet with bitcoins.

Figure 6. Dominant market solution for prepaid instruments in Poland in the year 2020

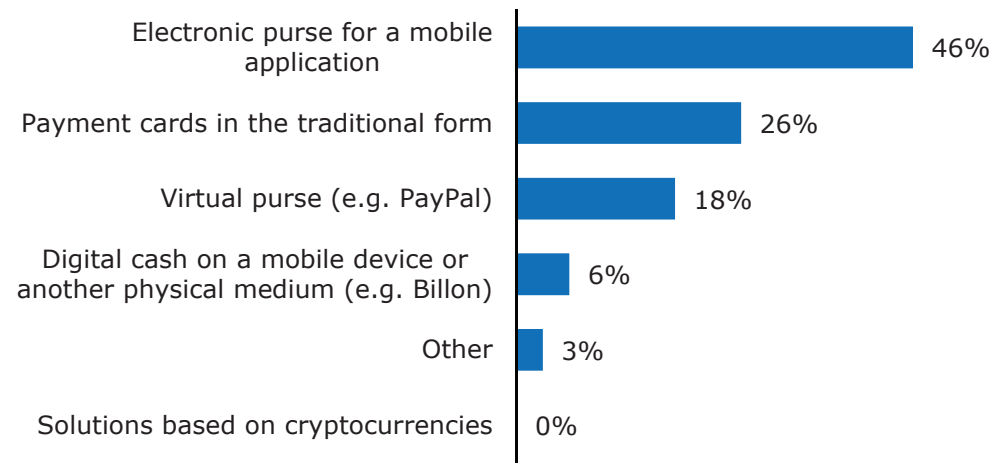

S o u r c e : survey of representatives of institutions operating in the payment services market in Poland, single choice, $\mathrm{N}=65$.

10 One such attempt to extend the functionalities of bitcoin the Polish market was made by BitBay, a platform for trading cryptocurrencies. In May 2016, it allowed for linking the account within its exchange with a prepaid card. Registered users may order a dedicated prepaid card and credit it directly with funds stored at BitBay, https:// bitbay.net/cards/index (accessed: 26.07.2016). 
However, it should be stressed that all of the experts participating in the survey believed that the very technology used to create bitcoin and other cryptocurrencies would not be used at all in the construction of prepaid instruments.

\section{ConCLUSIONS}

The results of the survey questionnaire among the representatives of financial institutions operating in Poland indicate that the payment services market will face a number of changes by the year 2020. The responses anticipate the development of non-banking competition and the marketing of many payment innovations.

The author believes that cryptocurrencies, and bitcoin in particular, have revolutionised the functioning of modern payment systems. Internet users are able to make payment transfers using the bitcoin cryptocurrency, which offer high levels of security and anonymity and boast low transaction costs. These features may have led the experts to perceive cryptocurrencies as a significant challenge to be faced by the whole sector by the year 2020. However, at the same time the experts are of the opinion that this innovation will not gain prominence in any of the analysed segments of the payment services market in Poland. Therefore, it is justified to conclude that the research hypothesis presented in the paper has been disproved. It does not, however, mean that the cryptocurrency project is a failure. The author is of the opinion that there is a good chance that business and public administration ${ }^{11}$ may use the blockchain which is the technological solution underlying the bitcoin system.

\section{U11 REFERENCES}

Badev, A. \& Chen, M. (2014). Bitcoin: Technical Background and Data Analysis. Finance and Economics Discussion Series, Divisions of Research \& Statistics and Monetary Affairs, Federal Reserve Board, Washington.

11 In 2016, the Ministry of Digital Affairs of the Republic of Poland appointed a working party, Blockchain and Cryptocurrencies Stream, in order to study and indicate practical uses of the blockchain and cryptocurrencies in the economy. The author is a member of that party; https://mc.gov.pl/projekty/od-papierowej-do-cyfrowej-polski/strumien-blockchain-i-kryptowaluty (20.01.2017). 
Baek, C., \& Elbeck, M. (2015). Bitcoins as an investment or speculative vehicle? A first look. Applied Economics Letters, 22(1), 30-34. doi: http://dx.doi.org/10.1080/135 04851.2014.916379.

Barber, S., Boyen, X., Shi, E., \& Uzun, E. (2012). Bitter to Better - How to Make Bitcoin a Better Currency. Financial Cryptography and Data Security, Vol. 7397, 399. doi: http://dx.doi.org/10.1007/978-3-642-32946-3_29.

Biuro KomunikacjiSpołecznej MinisterstwaSkarbu Państwa (2014).Bankowośćmobilna w Polsce - dynamiczny segment na fali wzrostu, https://www.msp.gov.pl/pl/przeksztalcenia/serwis-gospodarczy/wiadomosci-gospodarcze/28063,Bankowosc-mobilna-w-Polsce-dynamiczny-segment-na-fali-wzrostu.html (accessed: 20.07.2016).

Brito, J. \& Castillo, A. (2016). Bitcoin. A primer for policymakers, Mercatus Center at George Mason University.

Coindesk (2016), Who is Satoshi Nakamoto, http://www.coindesk.com/information/ who-is-satoshi-nakamoto/ (accessed: 26.08.2016).

Courtois, N.T., Grajek, M., Naik, R. (2014). Optimizing SHA256 in Bitcoin Mining. Cryptography and Security Systems, Vol. 448, 131-144. doi: http://dx.doi.org/10.1007/9783-662-44893-9_12.

European Central Bank (2012), Virtual currency schemes, Frankfurt am Main.

Franco, P. (2015). Understanding Bitcoin: Cryptography, Engineering and Economics, Wiley.

Grover, E. (2014). The sorrows of young Bitcoin. Digital Transactions, 39-40.

Harasim, J. (2013). Regulacje jako determinanta rozwoju innowacji na rynku płatności detalicznych. Annales UMCS - Sectio H Oeconomia, Vol. XLVII, No. 3, 219-228.

Harasim, J., \& Klimontowicz, M. (2013). Payment habits as a determinant of retail payment innovations diffusion: the case of Poland. Journal of Innovation Management, 1(2), 86-102.

International Monetary Fund (2016). Virtual Currencies and Beyond: Initial Considerations. IMF Staff Discussion Note, January 2016.

Kristoufek, L. (2015). What are the main drivers of the Bitcoin price? Evidence from wavelet coherence analysis. PLoS ONE, 10(4), e0123923. doi: http://dx.doi. org/10.1371/journal.pone.0123923.

Li, X. \& Wang, C.A. (2016). The technology and economic determinants of cryptocurrency exchange rates: The case of Bitcoin. Decision Support Systems. doi: http://dx.doi. org/10.1016/j.dss.2016.12.001.

Mikowska, M. (2015). POLSKA.JEST.MOBI 2015, http://www.tnsglobal.pl/coslychac/ files/2015/05/POLSKA_JEST_MOBI_2015.pdf (accessed: 17.07.2016).

Ministry of Digital Affairs of the Republic of Poland, https://mc.gov.pl/projekty/odpapierowej-do-cyfrowej-polski/strumien-blockchain-i-kryptowaluty (accessed: 20.01.2017).

Moore, T. (2013). The promise and perils of digital currencies. International Journal of Critical Infrastructure Protection, Vol. 6, 147-149. doi: http://dx.doi.org/10.1016/j. ijcip.2013.08.002.

Nakamoto, S. (2008), Bitcoin: A Peer-to-Peer Electronic Cash System, https://bitcoin. org/bitcoin.pdf (accessed: 06.05.2016). 
Nian, L.P. \& Chuen, D.L.K. (2015). Introduction to Bitcoin. In D.L.K. Chuen (Ed.), Handbook of Digital Currency. Bitcoin, Innovation, Financial Instruments, and Big Data, Elsevier.

Ober, M., Katzenbeisser S., Hamacher K. (2013). Structure and anonymity of the Bitcoin transaction graph. Future Internet, 5(2), 237-250. doi: http://dx.doi.org/10.3390/ fi5020237.

Polasik, M. (2014). Perspektywy rozwoju mobilnych płatności NFC na rynku polskim. Annales UMCS - Sectio H Oeconomia, Vol. XLVIII, No. 4, 197-207. doi: http://dx.doi. org/10.17951/h.2014.48.4.197.

Polasik, M., Piotrowski, D. (2016). Payment innovations in Poland: the role of payment services in the strategies of commercial banks. Ekonomia I Prawo. Economics and Law, 15(1), 73-101. doi: http://dx.doi.org/10.12775/EiP.2016.006.

Polasik M., Piotrowska A.I., Kumkowska N. (2015), Rozwój przez innowacje czy efekt skali? Badanie uczestników polskiego systemu płatniczego, Raport badawczy, ALTERUM - Ośrodek Badań i Analiz Systemu Finansowego, Warszawski Instytut Bankowości, Warszawa.

Polasik, M., Piotrowska, A., Wisniewski, T.P., Kotkowski, R., Lightfoot, G. (2015). Price Fluctuations and the Use of Bitcoin: An empirical Inquiry. International Journal of Electronic Commerce, 20(1), 9-49. doi: http://dx.doi.org/10.1080/10864415.2016. 1061413.

Selgin, G. (2015). Synthetic commodity money. Journal of Financial Stability, Vol. 17, $92-$ 99. doi: http://dx.doi.org/10.1016/j.jfs.2014.07.002.

Sieroń, A. (2013). Czym jest Bitcoin? Ekonomia - Wroclaw Economic Review. Acta Universitatis Wratislaviensis, 19(4), 31-51.

Świecka, B. (2015). Płatności mobilne jako innowacje na rynku detalicznych płatności bezgotówkowych. Problemy Zarządzania, 13(3), 29-40. doi: http://dx.doi. org/10.7172/1644-9584.54.2.

Vasek, M., Thornton, M., Moore T. (2014). Empirical Analysis of Denial-of-Service Attacks in the Bitcoin Ecosystem. Financial Cryptography and Data Security, Vol. 8438, 57-71. doi: http://dx.doi.org/10.1007/978-3-662-44774-1_5.

World Payment Report 2013 (2013). Capgemini, The Royal Bank of Scotland.

World Payment Report 2015 (2015). Capgemini, The Royal Bank of Scotland.

Yermack, D. (2013). Is Bitcoin a real currency? An economic appraisal. NBER Working Paper Series, No. 19747.

50 największych banków w Polsce 2015 (2015). Miesięcznik Finansowy BANK, http:// www.alebank.pl//images/stories/pdf/bank/2015/2015.06/bank.2015.06.034041.pdf (accessed:14.06.2016). 
